\title{
ANALISIS KLOROFIL DAN PERTUMBUHAN EKSPLAN KACANG KEDELAI (Glycine max (L.) Merr.) KULTIVAR ANJASMORO SECARA In Vitro DENGAN PEMBERIAN AIR KELAPA (Cocos nucifera L.)
}

\author{
Endang Nurcahyani ${ }^{*}$, Della Apriyanti ${ }^{2}$, Sri Wahyuningsih ${ }^{2}$, Mahfut $^{2}$ \\ ${ }^{1}$ Program Studi Biologi Terapan, Jurusan Biologi, FMIPA, Universitas Lampung \\ ${ }^{2}$ Program Studi Biologi, Jurusan Biologi, FMIPA,Universitas Lampung \\ Jalan Prof. Dr. Soemantri Brodjonegoro No.1 Bandar Lampung 35145 \\ endang.nurcahyani@fmipa.unila.ac.id
}

\begin{tabular}{|l|}
\hline Artikel Info \\
Diterima \\
tanggal \\
12.09 .2019 \\
Disetujui \\
publikasi \\
tanggal \\
30.04 .2020 \\
Kata kunci : \\
Kultur jaringan \\
murashige, \\
skoog, soybeans
\end{tabular}

\begin{abstract}
ABSTRAK
Perbanyakan kacang kedelai (Glycine max L.) dengan menggunakan teknik kultur jaringan dapat membantu memperbanyak tanaman dengan menghasilkan biji yang mempunyai keunggulan, antara lain mampu menghasilkan biji dalam jumlah yang besar dengan waktu yang singkat dan tidak membutuhkan tempat yang luas, kesehatan dan mutu biji lebih terjamin serta kecepatan tumbuh biji lebih cepat. Penelitian ini menggunakan medium Murashige and Skoog (MS) dengan pemberian air kelapa. Penelitian ini bertujuan untuk mengetahui efek pemberian air kelapa terhadap jumlah planlet yang hidup serta untuk mengetahui kandungan klorofil a, klorofil b, dan klorofil total optimum pada planlet kacang kedelai kultivar anjasmoro. Penelitian ini menggunakan Rancangan Acak Lengkap (RAL) dengan satu faktor yaitu konsentrasi air kelapa dengan 4 taraf perlakuan: $0 \%, 5 \%, 10 \%$, dan 15\% dengan 6 ulangan. Data dianalisis dengan menggunakan uji Levene dan uji lanjut dengan Beda Nyata Terkecil (BNT) pada taraf 5\%. Hasil penelitian menunjukkan bahwa hasil persentase planlet yang hidup menunjukkan hasil $100 \%$ hidup, dan pemberian air kelapa belum memberikan pengaruh terhadap kandungan klorofil a, klorofil b, dan klorofil total.
\end{abstract}

\begin{abstract}
Propagation of soybeans (Glycine max L.) by using tissue culture techniques can help multiply plants by producing seeds that have advantages, such as being able to produce large amounts of seeds in a short time and do not require a large place, health and quality of seeds are guaranteed and the speed of growing more seeds fast. This research uses Murashige and Skoog (MS) as a medium by giving coconut water. This study aims to determine the effect of coconut water administration on the number of living plantlets and to determine the optimum content of chlorophyll a, chlorophyll b, and total chlorophyll in anjasmoro cultivar soybean planlets. This study uses a completely randomized design (CRD) with one factor, namely coconut water concentration with 4 levels of treatment: $0 \%, 5 \%, 10 \%$, and 15\% with 6 replications. Data were analyzed using the Levene test and follow-up tests with the Least Significant Difference (LSD) at the 5\% level. The results showed that the results of the percentage of plantlets that lived showed $100 \%$ live results, and the provision of coconut water had not affected the content of chlorophyll a, chlorophyll b, and total chlorophyll.
\end{abstract}

doi: http://dx.doi.org/10.23960/aec.v5.i2.2020.p101-110 Anal.Environ.Chem. 


\section{PENDAHULUAN}

Kacang kedelai (Glycine max L.) merupakan salah satu komoditas pertanian yang sangat dibutuhkan di Indonesia. Banyaknya manfaat yang diperoleh dari kacang kedelai seperti sebagai sumber protein nabati, juga mengandung mineral-mineral seperti $\mathrm{Ca}, \mathrm{P}$, dan $\mathrm{Fe}$ serta kandungan vitamin A dan B (Sudaryanto dan Swasti, 2007). Kacang kedelai sangat akrab dalam pola makanan sehari-hari. Kebutuhan kacang kedelai terus meningkat setiap tahun sejalan dengan meningkatnya jumlah penduduk dan perkembangan industri yang membutuhkan bahan baku kacang kedelai. Peningkatan ini tidak diimbangi dengan peningkatan produksi kacang kedelai di Indonesia (Giono, 2014 dan Savitri, 2008).

Menurut Fauzy dkk. (2016), tanaman dapat dikembangbiakkan secara generatif dan vegetatif. Salah satu teknik pembiakan tanaman vegetatif yaitu dengan cara kultur jaringan tanaman. Berbagai komposisi medium kultur telah diformulasikan untuk mengoptimalkan pertumbuhan dan perkembangan tanaman yang dikulturkan. Beberapa jenis formulasi medium bahkan digunakan secara umum untuk berbagai jenis eksplan dan varietas tanaman, seperti medium Murashige \& Skoog (MS) yang digunakan untuk perkecambahan biji, medium Vacin Went (VW) untuk anggrek, dan medium Woody Plant Medium (WPM) untuk tanaman berkayu (Yusnita, 2003). Saat ini sudah banyak penelitian dengan menggunakan medium MS yang dimodifikasi. Modifikasi medium dimaksudkan untuk mengetahui kebutuhan hara yang tepat bagi eksplan untuk tumbuh dan berkembang pada medium kultur jaringan dan terbebas dari kontaminan (Fauzy dkk., 2016).

Menurut Seswita (2010), Upaya peningkatan produksi kedelai dapat dilakukan dengan pemberian Zat Pengatur Tumbuh (ZPT). Air kelapa merupakan salah satu bahan alami yang dapat digunakan sebagai subtitusi zat pengatur tumbuh sintetik. Air kelapa mengandung sitokinin, auksin serta senyawa-senyawa lain yang dapat menstimulasi perkecambahan dan pertumbuhan (Morel dalam Prihatmanti dan Mattjik, 2004). Air kelapa banyak mengandung mineral antara lain natrium $(\mathrm{Na})$, kalsium $(\mathrm{Ca})$, magnesium $(\mathrm{Mg})$, ferum $(\mathrm{Fe})$, cuprum $(\mathrm{Cu})$, posfor (P) dan sulfur (S). Selain kaya mineral, air kelapa juga mengandung gula antara 1,7 gram sampai 2,6\%, protein 0,07 hingga 0,55 \% dan mengandung berbagai macam vitamin seperti

doi: http://dx.doi.org/10.23960/aec.v5.i2.2020.p101-110 Anal.Environ.Chem. 
asam sitrat, asam nikotina, asam pantotenal, asam folat, niacin, riboflavin, thiamin, mengandung hormon auksin dan sitokinin (Yuliawati, 2006).

Klorofil merupakan pigmen pemberi warna hijau pada tumbuhan, alga dan bakteri fotosintetik. Pigmen ini berperan dalam proses fotosintesis tumbuhan dengan menyerap dan mengubah energi cahaya menjadi energi kimia. Klorofil mempunyai rantai fitil $\left(\mathrm{C}_{20} \mathrm{H}_{39} \mathrm{O}\right)$ yang akan berubah menjadi fitol $\left(\mathrm{C}_{20} \mathrm{H}_{39} \mathrm{OH}\right)$ jika terkena air dengan katalisator klorofilase. Fitol adalah alkohol primer jenuh yang mempunyai daya afinitas yang kuat terhadap $\mathrm{O}_{2}$ dalam proses reduksi klorofil (Muthalib, 2009).

Klorofil merupakan komponen utama kloroplast untuk fotosintesis. Semakin tinggi kandungan klorofil maka semakin tinggi tingkat fotosintesis (Nurcahyani dkk., 2019). Klorofil memiliki tiga fungsi utama dalam proses fotosintesis yaitu memicu fiksasi $\mathrm{CO}_{2}$ untuk menghasilkan karbohidrat, menyediakan energi bagi ekosistem dan memanfaatkan energi matahari. Terdapat dua macam klorofil yaitu klorofil a $\left(\mathrm{C}_{55} \mathrm{H}_{72} \mathrm{O}_{5} \mathrm{~N}_{4} \mathrm{Mg}\right)$ yang berwarna hijau tua dan klorofil b $\left(\mathrm{C}_{55} \mathrm{H}_{70} \mathrm{O}_{6} \mathrm{~N}_{4} \mathrm{Mg}\right)$ yang berwarna hijau muda. Klorofil a dan klorofil b paling kuat menyerap cahaya di bagian merah (600-700 nm), dan paling sedikit menyerap cahaya hijau (500$600 \mathrm{~nm})$ (Song dan Banyo, 2011).

Difisit air akan mempengaruhi perubahan fungsi metabolisme, terutama mengurangi sintesis klorofil. Penurunan konsentrasi klorofil daun merupakan salah satu respon fisiologi tanaman akibat kekurangan air yang menyebabkan penghambatan pembentukan klorofil, penghambatan nutrisi, terutama pada hormon nitrogen dan magnesium yang berperan penting dalam sintesis klorofil (Nurcahyani dkk., 2019).

\section{METODE}

\section{Alat dan Bahan}

Alat-alat yang digunakan dalam penelitian ini adalah Laminar Air Flow (LAF) Cabinet merk Esco sebagai meja steril yang dilengkapi dengan blower dan lampu UV untuk penanaman eksplan atau subkultur tunas pada medium dalam botol, autoclave digunakan sebagai sterilisasi basah, plastic wrap, scalpel, magnetic stirrer, hot plate atau kompor, alumunium foil, label, bunsen, beaker glass, gelas ukur, batang pengaduk, botol kultur, pipet tetes, cawan petri, pinset,

doi: http://dx.doi.org/10.23960/aec.v5.i2.2020.p101-110 Anal.Environ.Chem. 
gunting, neraca analitik, $\mathrm{pH}$ meter, kertas Whatman No 1, spektrofotometer, mortar, karet gelang, mistar, lemari kultur, tissue, tabung gas, panci, korek api, kamera hp, masker dan sarung tangan.

Bahan-bahan yang digunakan adalah eksplan kacang kedelai (Glycine max L.) Kultivar Anjasmoro, medium Murashige and Skoog (MS) "use ready" diproduksi oleh Caisson Laboratories, agar-agar 7g/L, gula 30g/L, KOH 1 N, HCL 1 N, PPM 0,5 ml/L, air kelapa dengan konsentrasi $0 \%, 5 \%, 10 \%$, dan $15 \%$, alkohol $70 \%$ dan $96 \%$, aquades dan spiritus.

\section{Prosedur}

Medium tanam dibuat sebanyak 1 L. Pembuatan medium Murashige and Skoog (MS) dilakukan dengan cara medium MS "use ready" ditimbang sebanyak 4,43 g/L, lalu dicampurkan dengan gula $30 \mathrm{~g} / \mathrm{L}$, kemudian dilarutkan menggunakan aquades secukupnya ke dalam beaker glass dengan menggunakan magnetic stirrer dan diletakkan di atas hotplate. Medium MS yang sudah dilarutkan dimasukkan ke dalam gelas ukur, kemudian ditambah aquades mencapai volume $1000 \mathrm{ml}$. Larutan medium dimasukkan ke dalam panci dan diukur pH-nya hingga mencapai 5,7 dalam kondisi netral (apabila medium terlalu asam maka ditambahkan $\mathrm{KOH} 1 \mathrm{~N}$ dan apabila medium terlalu basa maka ditambahkan HCL 1 N). Agar sebanyak 7 gr/L dan PPM 0,5 ml/L dimasukkan ke dalam panci, lalu dimasak dan diaduk hingga mendidih. Selanjutnya, medium tersebut dituangkan ke dalam botol masing-masing sebanyak $20 \mathrm{ml} /$ botol kultur. Konsentrasi $0 \%$ (control) tidak diberi perlakuan, tetapi perlakuan ditetesi air kelapa (5\%, 10\%, dan 15\%) sebanyak 20 tetes ke dalam masing-masing botol kultur, tutup menggunakan alumunium foil, dan diberi label menggunakan pensil pada masing-masing perlakuan.

Penanaman biji kacang kedelai dilakukan di dalam LAF Cabinet. Langkah pertama biji kacang kedelai direndam dalam bayclean selama 5 menit lalu dibilas dengan air mengalir sebanyak 3 kali. Setelah itu direndam dalam larutan bayclin 20\% selama 2-3 menit. Biji kacang kedelai dibilas dengan aquades, pembilasan dilakukan sebanyak dua kali. Setelah itu dipindahkan ke dalam cawan petri selanjutnya benih ditanam pada medium seleksi dengan penambahan air kelapa. Setiap botol kultur ditanami 2 biji, sehingga total biji yang ditanam

doi: http://dx.doi.org/10.23960/aec.v5.i2.2020.p101-110 Anal.Environ.Chem. 
sebanyak 48 dalam 24 botol kultur. Biji-biji kacang kedelai tersebut di tumbuhkan hingga menjadi planlet pada medium MS.

Analisis kandungan klorofil menggunakan daun planlet kacang kedelai kultivar anjasmoro yang sudah diberikan perlakuan kombinasi medium MS dengan air kelapa, menggunakan metode Miazek (2002) dengan spektrofotometer yang dilakukan pada akhir pengamatan. Daun planlet Glycine max kultivar anjasmoro sebanyak 0,1 g dihilangkan ibu tulang daunnya, digerus dengan mortar, ditambahkan $10 \mathrm{~mL}$ ethanol. Larutan disaring dengan kertas Whatman No.1 dan dimasukkan ke dalam flakon lalu ditutup rapat. Larutan sampel dan larutan standar (ethanol) diambil sebanyak $1 \mathrm{~mL}$ dimasukkan dalam kuvet. Setelah itu dilakukan pembacaan serapan dengan spektrofotometer UV pada panjang gelombang ( $\lambda$ ) $648 \mathrm{~nm}$ dan 664 nm, dengan tiga kali ulangan sampel.

\section{HASIL DAN PEMBAHASAN}

\section{A. Persentase Jumlah planlet yang hidup}

Planlet yang steril dihitung sebagai eksplan yang mampu merespon unsur hara dan ZPT hingga 4 MST dan selama masa perlakuan dilakukan pengamatan pertumbuhan dalam medium tanam yang memiliki ciri morfologi yang seragam (Tabel 1).

Tabel 1. Persentase jumlah planlet kacang kedelai kultivar Anjasmoro yang hidup setelah penambahan air kelapa (Cocos nucifera L.) pada berbagai konsentrasi.

\begin{tabular}{ccccc}
\hline \multirow{2}{*}{$\begin{array}{c}\text { Konsentrasi } \\
\text { Air kelapa (\%) }\end{array}$} & \multicolumn{4}{c}{$\begin{array}{c}\text { Persentase Jumlah Planlet Hidup } \\
\text { pada Minggu Ke- }(\%)\end{array}$} \\
\cline { 2 - 5 } & I & II & III & IV \\
\hline 0 & 100 & 100 & 100 & 100 \\
5 & 100 & 100 & 100 & 100 \\
10 & 100 & 100 & 100 & 100 \\
15 & 100 & 100 & 100 & 100 \\
\hline
\end{tabular}

Berdasarkan Tabel 1, dapat diketahui bahwa perlakuan dengan penambahan air kelapa pada berbagai konsentrasi yaitu 0\%,5\%, 10\%, dan 15\% terhadap planlet kacang kedelai kultivar Anjasmoro pada minggu ke-I sampai minggu ke-IV didapatkan 100\% planlet hidup dan tidak ada yang mati. Planlet yang hidup ditunjukkan dengan bertambahnya tinggi planlet,

doi: http://dx.doi.org/10.23960/aec.v5.i2.2020.p101-110 Anal.Environ.Chem. 
bertambahnya daun, dan munculnya tunas pada planlet. Jumlah sampel per perlakuan yang dicobakan sebanyak 2 sampel kacang kedelai kultivar Anjasmoro pada setiap botol kultur. Selanjutnya eksplan kacang kedelai kultivar Anjasmoro ditanam pada medium perlakuan, kemudian diamati hingga eksplan berumur 4 minggu setelah perlakuan. Pertumbuhan planlet disajikan pada Gambar 1.
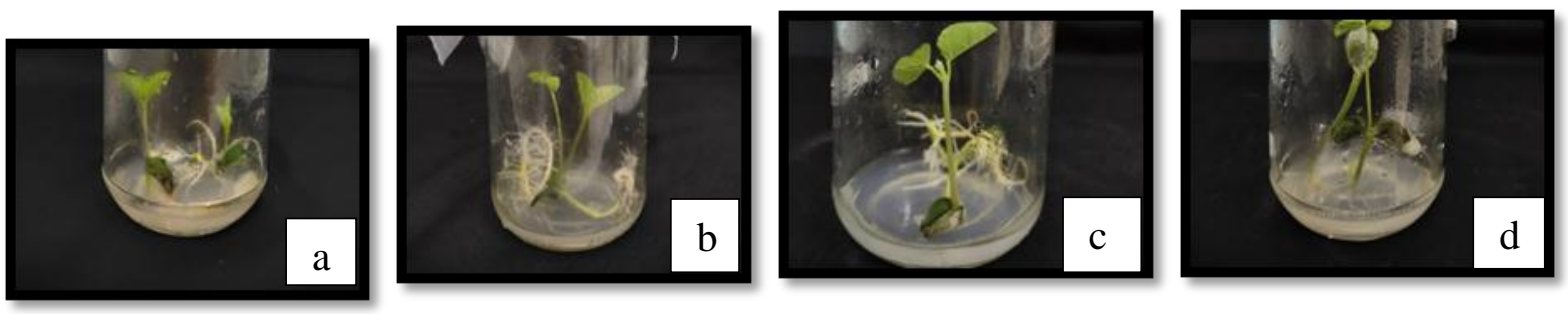

Gambar 1. Pertumbuhan planlet a. Pertumbuhan planlet 0\%, b. Pertumbuhan planlet 5\%, c. Pertumbuhan planlet $10 \%$, d. Pertumbuhan planlet $15 \%$

\section{B. Kandungan Klorofil}

Analisis ini dilakukan untuk mengetahui kandungan klorofil yang terdapat pada planlet kacang kacang kedelai kultivar Anjasmoro yang telah ditanam di medium MS dan ditambahkan air kelapa dengan berbagai konsentrasi. Analisis kandungan klorofil yang dilakukan ini terdiri dari analisis kandungan klorofil a, klorofil b, dan klorofil total yang diukur dengan menggunakan spektrofotometer UV pada panjang gelombang $648 \mathrm{~nm}$ dan $664 \mathrm{~nm}$.

\section{Kandungan Klorofil a}

Kandungan klorofil a pada daun kacang kedelai kultivar Anjasmoro yang diberikan perlakuan penambahan air kelapa dengan berbagai konsentrasi disajikan pada Tabel 2. Hasil analisis ragam pada taraf 5\% menunjukkan bahwa pemberian air kelapa ke dalam medium MS tidak berpengaruh nyata $(0,933>0,05)$ terhadap kandungan klorofil a kacang kedelai kultivar Anjasmoro. Hal ini menunjukkan bahwa pemberian air kelapa tidak memberikan pengaruh nyata dalam meningkatkan kandungan klorofil a, hal ini diduga karena konsentrasi air kelapa yang diberikan tidak sesuai.

doi: http://dx.doi.org/10.23960/aec.v5.i2.2020.p101-110 Anal.Environ.Chem. 
Tabel 2. Rerata kandungan klorofil a daun kacang kedelai kultivar Anjasmoro per konsentrasi pada pengamatan minggu ke-4 kultur in vitro.

\begin{tabular}{cc}
\hline Konsentrasi Air Kelapa (\%) & Kandungan Klorofil a \\
\hline 0 & $3,07 \pm 0,83$ \\
5 & $3,12 \pm 0,63$ \\
10 & $2,96 \pm 0,32$ \\
15 & $3,50 \pm 0,57$ \\
\hline
\end{tabular}

\section{Keterangan :}

Klorofil $a=\bar{Y} \pm S E$

$\bar{Y}=$ Rata-rata klorofil a

$S E=$ Standar error

Berdasarkan hasil analisis menunjukkan bahwa penggunaan medium MS dengan penambahan air kelapa yang cukup dapat meningkatkan kandungan klorofil a pada planlet kacang kedelai kultivar Anjasmoro. Klorofil a pada daun nampak berwarna hijau-tua. Klorofil a memiliki rumus kimia $\left(\mathrm{C}_{55} \mathrm{H}_{72} \mathrm{O}_{5} \mathrm{~N}_{4} \mathrm{Mg}\right)$ dengan gugus pengikat $\mathrm{CH}_{3}$ (Dwidjoseputro, 1980). Menurut Gardner dkk. (1991) menyatakan bahwa klorofil a menyerap cahaya biru-violet dan merah dengan absorpsi maksimum dengan panjang gelombang $673 \mathrm{~nm}$.

\section{Kandungan Klorofil b}

Kandungan klorofil b pada daun kacang kedelai kultivar Anjasmoro yang diberikan perlakuan penambahan air kelapa dengan berbagai konsentrasi disajikan pada Tabel 3. Hasil analisis ragam pada taraf 5\% menunjukkan bahwa pemberian air kelapa ke dalam medium MS tidak berpengaruh nyata $(0,706>0,05)$ terhadap kandungan klorofil $\mathrm{b}$ kacang kedelai kultivar Anjasmoro. Hal ini menunjukkan bahwa pemberian air kelapa tidak memberikan pengaruh nyata dalam meningkatkan kandungan klorofil $b$, hal ini diduga karena konsentrasi air kelapa yang diberikan tidak sesuai. Berdasarkan hasil analisis menunjukkan bahwa penggunaan medium MS dengan penambahan air kelapa yang cukup dapat meningkatkan kandungan klorofil a pada planlet kacang kedelai kultivar Anjasmoro.

doi: http://dx.doi.org/10.23960/aec.v5.i2.2020.p101-110 Anal.Environ.Chem. 
Tabel 3. Rerata kandungan klorofil b daun kacang kedelai kultivar Anjasmoro per konsentrasi pada pengamatan minggu ke-4 kultur in vitro.

\begin{tabular}{cc}
\hline Konsentrasi Air Kelapa (\%) & Kandungan Klorofil b \\
\hline 0 & $2,14 \pm 0,42$ \\
5 & $1,79 \pm 0,43$ \\
10 & $2,17 \pm 0,19$ \\
15 & $2,38 \pm 0,31$ \\
\hline
\end{tabular}

\section{Keterangan :}

Klorofil $b=\bar{Y} \pm S E$

$\bar{Y}=$ Rata-rata klorofil b

$S E=$ Standar error

\section{Kandungan Klorofil Total}

Tabel 4. Rerata kandungan klorofil total daun kacang kedelai kultivar Anjasmoro per konsentrasi pada pengamatan minggu ke-4 kultur in vitro.

\begin{tabular}{cc}
\hline Konsentrasi Air Kelapa $(\boldsymbol{\%})$ & Kandungan Klorofil Total \\
\hline 0 & $5,21 \pm 1,25$ \\
5 & $5,53 \pm 1,01$ \\
10 & $5,13 \pm 0,50$ \\
15 & $5,88 \pm 0,88$ \\
\hline
\end{tabular}

\section{Keterangan :}

Klorofil total $=\bar{Y} \pm S E$

$\bar{Y}=$ Rata-rata klorofil total

$S E=$ Standar error

Kandungan klorofil total pada daun kacang kedelai kultivar Anjasmoro yang diberikan perlakuan penambahan air kelapa dengan berbagai konsentrasi disajikan pada Tabel 4. Hasil analisis ragam pada taraf 5\% menunjukkan bahwa pemberian air kelapa ke dalam medium MS tidak berpengaruh nyata $(0,941>0,05)$ terhadap kandungan klorofil total kacang kedelai kultivar Anjasmoro. Hal ini menunjukkan bahwa pemberian air kelapa tidak memberikan pengaruh nyata dalam meningkatkan kandungan klorofil total, hal ini diduga karena konsentrasi air kelapa yang diberikan tidak sesuai. Berdasarkan hasil analisis menunjukkan bahwa penggunaan medium MS

doi: http://dx.doi.org/10.23960/aec.v5.i2.2020.p101-110 Anal.Environ.Chem. 
dengan penambahan air kelapa yang cukup dapat meningkatkan kandungan klorofil a pada planlet kacang kedelai kultivar Anjasmoro.

Pemberian air kelapa belum memberikan respon dalam meningkatkan kandungan klorofil a, klorofil b, dan total. Hal ini terjadi karena kemungkinan planlet kacang kedelai kultivar Anjasmoro belum dapat menstimulasi klorofil a, b maupun total dengan baik, terbukti dengan adanya kotiledon yang menempel pada planlet, ini menunjukkan bahwa planlet kacang kedelai kultivar Anjasmoro belum maksimal dalam melakukan fotosintesis dan masih menggunakan cadangan makanan pada kotiledon dalam pertumbuhannya. Penurunan kandungan klorofil pada saat tanaman kekurangan air akan berkaitan dengan aktivitas fotosintesis dan menurunkan laju fotosintesis tanaman sehingga pembentukan klorofil terhambat (Song, 2011).

\section{KESIMPULAN}

Berdasarkan penelitian yang telah dilakukan dapat disimpulkan bahwa pemberian air kelapa pada persentase planlet yang hidup menunjukkan $100 \%$ hidup, tetapi belum memberikan reaksi terhadap kandungan klorofil a, b, dan total.

\section{DAFTAR PUSTAKA}

Dwijoseputro, D. 1994. Pengantar Fisiologi Tumbuhan. Gramedia. Jakarta.

Fauzy, E., Mansyur dan Husni, A. 2016. Pengaruh Media Murashige and Skoog (MS) dan Vitamin Terhadap Tekstur, Warna dan Berat Kalus Rumput Gajah (Pennisetum purpureum) CV. Hawaii Pasca Radiasi Sinar Gamma Pada Dosis Ld50 (In Vitro). Universitas Padjadjaran. Bandung. Halaman 1-17.

Giono. 2014. Ketahanan genotipe kedelai terhadap kekeringan dan Kemasaman, hasil induksi mutasi dengan sinar gamma. Fakultas Pertanian. Universitas Hasanudin.

Harjadi. 2009. Zat Pengatur Tumbuh. Penebar Swadaya. Jakarta.

Li, R., Guo, P., Baum, M., Grando, S., Ceccarelli, S. 2006. Evaluation of Chlorophyll Content and Fluorescence Parameters as Indicators of Drought Tolerance in Barley. Agricultural Sciences in China 5 (10): 751-757.

Muthalib, A. 2009. Klorofil dan Penyebaran di Perairan. http://wwwabdulmuthalib. co.cc/2009/06/. Diakses pada tanggal 11 Oktober 2019.

doi: http://dx.doi.org/10.23960/aec.v5.i2.2020.p101-110 Anal.Environ.Chem. 
Nurcahyani, E., Sumardi, Qudus. H. I., Palupi, A., dan Sholekhah. 2019. Analysis of Chlorophyll Phalaenopsis amabilis (L.) Bl. Result of the Resistance to Fusarium oxysporum and Drought Stress. Journal of Agriculture and Veterinary Science (IOSR-JAVS). 12(11): 44.

Prihatmanti, D. dan Mattjik, N.A. 2004. Penggunaan ZPT NAA dan BAP serta air kelapa untuk mendeteksi organogenesis tanaman anthorium (Anthorium andreamum L. Ex Andre). Bul. Agronomi 32: 20-25.

Savitri. 2008. Rahasia Tumbuhan Berkhasiat Obat Perspektif Islam. UIN Press. Malang.

Seswita, D. 2010. Penggunaan Air Kelapa Sebagai Zat Pengatur Tumbuh pada Multiplikasi Tunas Temulawak (Curcuma xanthorrhiza) In Vitro. Jurnal Littri, 16(4): 135 - 140.

Song, N. A. dan Banyo, Y. 2011. Konsentrasi Klorofil Daun Sebagai Indikator Kekurangan Air Pada Tanaman. Jurnal Ilmiah Sains. 11(2): 171.

Sudaryanto, T. dan Swastika, D. K. S. 2007. Ekonomi Kedelai di Indonesia. Kedelai Teknik Produksi dan Pengembangan. Badan Penelitian dan Pengembangan Pertanian. Pusat Penelitian dan Pengembangan Tanaman Pangan.

Yuliawati. 2006. Air kelapa Berpengaruh Terhadap Pertumbuhan Tinggi Dan Jumlah Daun Pada Tanaman Nanas Hias (Neoregelia spectabilis) Pada Media Tanam Yang Berbeda. Skripsi : Fakultas Keguruan Dan Ilmu Pendidikan Biologi Universitas Muhammadiyah Surakarta.

Yusnita. 2003. Kultur Jaringan: Cara Memperbanyak Tanaman Secara Efisien. Agromedia Pustaka. Jakarta.

doi: http://dx.doi.org/10.23960/aec.v5.i2.2020.p101-110 Anal.Environ.Chem. 